Fecha de recepción: julio 2021 Fecha de aprobación: agosto 2021 Fecha publicación: septiembre 2021

\section{Communication by analogy: the contribution of memory as a facilitator of the perception of biomimetic artifacts}

Thamyres Oliveira Clementino ${ }^{(1)}$, Theska Laila de

F. Soares ${ }^{(2)}$ and Amilton José Vieira de Arruda ${ }^{(3)}$

\begin{abstract}
The formal-aesthetic function is related to the experience of sensory impressions of formal elements-morphology, in which the relationship between the object and the user occurs at the level of sensory processes. This is possible because material stuff speaks of themselves in terms of their configuration, making it possible to design objects that evoke memories. This article aims to show Analogy as a path for the communicational development of industrial artifacts, which can emphasize their uses through memories and previews experiences with natural structures. For this, it presents a literature review emphasizing the communicational character of biomimetic artifacts and their ability to evoke memory as a project strategy.
\end{abstract}

Keywords: Communication - Aesthetics - Memory - Experience - Product design - Biomimicry - Analogy - Biophilia

[Abstracts in spanish and portuguese at page 187]

(1) Thamyres Oliveira Clementino. Designer, $\mathrm{PhD}$ in Design from the Federal University of Pernambuco (UFPE) and master's in design from the Federal University of Campina Grande (UFCG). She taught the disciplines of Design II and Materials and Manufacturing Processes I and II in the Design course at the Federal University of Campina Grande (UFCG) and Web Design courses at the Science and Technology Center (CTCC). She works as a researcher with an interest in the areas of Planning and contextualization of artifacts. thamyres.oliveira.clementino@gmail.com (D) https://orcid.org/0000-0003-1323 $-2831$

(2) Theska Laila de Freitas Soares is PhD student, master and graduated in Design from the Federal University of Pernambuco (UFPE-BRA), has a specialization in Product and Interior Design from the FBV (BRA) partnership and the Istituto Europeo di Design (IED). She is the creative director at EDEN with professional experience in several areas of Design. She was a professor of Design at UNINASSAU (Recife-BRA) and a substitute for the Design department at UFPE (Agreste Campus). She has a strong focus on research in the areas of Biomimetics and Strategic Design. theska.soares@ufpe.br (D) https://orcid. org/0000-0001-5493-1087 
(3) Amilton José Vieira de Arruda. Graduation in Industrial Design Product Project by UFPE (1982), Master in Design and Bionics by IED in Milan (1992), Doctorate in Ricerca in Disegno Industriale - Ph.D by University of Milan Politecnico (2002) and postdoctoral in Design and Bionics at IADE European University UNIDCOM Lisbon (2018/2019). Since 1985 professor of the UFPE Design Course. He is currently associate professor IV. He coordinates the Research Group on Biodesign and Industrial Artifacts at UFPE. Organizer together with Edgard Blucher of the [DesignCONTEXTO] series design, culture and technology essays from the following books: (2017) 1. Design and Complexity; (2017) 2. Design and Social Innovation; (2018) 3. Design, Artifacts and Sustainable Systems; (2019) 4. Narratives and Languages in the creative process in Modeling and Prototyping (in press). Always with Edgar Blucher he organizes the series [designNATUREZA] essays on design, bionics and biomimetics with the following book: (2018) Methods and Processes in Bionics and Biomimetics: the technological revolution by nature. With the publisher Insigh in (2019) we launched the following title: Topics in Design: Biomimetics, Sustainability and New Materials; and recently with Blucher (2020) the Book: Design and Bionics. Carmelo Di Bartolo and Centro Ricerche IED: esperienze memorabili da 30 protagonisti. amilton. arruda@ufpe.br (D) https://orcid.org/0000-0003-4551-4497

\section{Communication by analogy: the contribution of memory as a facilitator of the perception of biomimetic artifacts}

The formal-aesthetic function is related to the experience of sensory impressions of formal elements - morphology (Bürdek, 2006), in which the relationship between the object and the user occurs at the level of sensory processes (Löbach, 2001). It depends on aspects such as shape, color, surface, among other information that allow the association of ideas. For Cardoso (2012), this is possible because material things speak of themselves in terms of their configuration, making it possible to project objects that evoke memories.

The author states that memory enables the individual to remember what he/she lived/ learned from associations, which arise through present situations or even from objects, supports for memory. As for the experience, Cardoso (2013) claims to have the potential to influence the perception of objects, being a relationship conditioned by previous experiences, which help in the judgment of current events.

Material objects can be designed with the purpose of evoking memories, generating recognition by the public. According to Cardoso (2012) it is possible to make strategic use of memory to refine projects, entrusting them with additional layers of meanings, and, in the case of products inspired by nature, creating analogies that facilitate their use.

The analogy is widely used by biomimicry and is useful in translating principles, forms, functions, processes, structures, etc. of natural references for artificial systems (Soares, 2016). It is also notorious the relationship with Biophilia, which uses forms of nature to promote well-being, caused, among other aspects, through memory and previous experience, familiar to people's repertoire. 
This article aims to show Analogy as a path for the communicational development of artifacts, which can emphasize their uses through memories and experiences with natural structures. For this, it presents a literature review and emphasizing the communicational character of biomimetic products and their ability to evoke memory as a project strategy.

\section{Aesthetic perception and memory}

Aesthetics can be approached from studies that are concerned with understanding sensory perception (Bomfim, 1995). In this view, everything that is mediated by the senses (sight, smell, taste, hearing, and touch) is considered aesthetic. It consists of a line of research linked to the concept of "product function", in which says Löbach (2001, p. 54), the "essential aspects of users' relations with industrial products" are treated, making them noticeable in the process of use, and enabling the satisfaction of needs.

For Löbach (2001), the functions performed by the product create a relationship with the user from the use, making it possible to establish positive impressions or not. In this context, each product coexists with different functions, which must be thought out to meet the needs of the user and the project, which are the practical, aesthetic, and symbolic function (See Figure 1).

Bürdek (2006) states that the formal-aesthetic function is related to the experience of sensory impressions of formal elements (morphology), in which, says Löbach (2001), it occurs to the relationship between the object and the user at the level of sensory processes. Silveira (2018) adds that the aesthetic function goes beyond the sensory factor, because the process involved culminates in the judgment, through the user's discernment. The author goes on to affirm that "when faced with the product, the user is able to psychically assimilate this information, reacting to it according to the content of the transmitted message" (Silveira, 2018, p. 79).

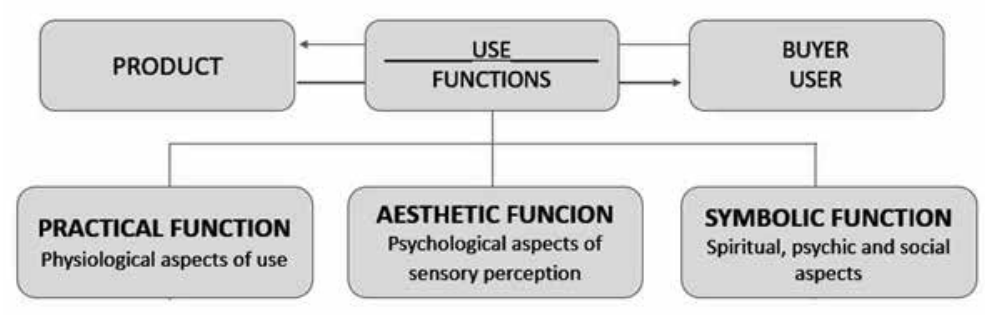

Figure 1. Functions present in products. 
Löbach (2001) corroborates with this argument by indicating that the aesthetic function and the symbolic function correspond to an interdependent relationship. The symbolic function establishes associations between the objects and the experiences and sensations experienced previously by the user. This is made possible through aesthetic and morphological aspects such as shape, color, surface, among other visual information, inherent to the aesthetic function. For Cardoso (2012), this is admissible, since material things speak of themselves in terms of their configuration, making it possible to design objects that evoke memories.

The author goes on to argue that memory enables the individual to remember what he lived/learned through associations, which occur through current events, or even through objects, which become supports for memory. As for the experience, Cardoso (2013) claims to be one of the conditioning factors of meaning, having the potential to influence the perception of objects. For him, the experience is the most immediate and intimate of each one with the objects. This relationship is conditioned by all the other previous experiences, which help in the judgment of current events/experiences, and, in the case of bioinspired products, may contribute to a quick understanding of structures/forms/functional systems applied to the products.

It is possible to conjecture that material objects can be designed with the purpose of evoking memories linked to specific identities, generating recognition by the public. This is pertinent since for Cardoso (2012) it is possible to make a strategic use of memory to refine projects, entrusting them with additional layers of meanings, and, in the case of bioinspired products, assigning greater ease in the first contact of users with industrial products, by analogy to natural structures.

To create the aesthetic function of a product, it is necessary to take into account the perceptual conditions of individuals capable of endowing objects with aesthetic functions aligned with memory. When designing the aesthetic function, based on aesthetic criteria, it is possible to contribute so that the individual recognizes the information that surrounds him, bringing him greater comfort, through the conditions of perception (Löbach, 2001). To understand the sensory use of objects, two factors are essential (Löbach, 2001):

1. Previous experiences with aesthetic characteristics, and

2. Conscious awareness of these characteristics.

In this perspective, it is pertinent to reinforce that bioinspired products have the capacity to evoke the visual memory of individuals, contributing to the recognition of products created by analogy, facilitating their use. For Cardoso (2013), the visual and morphological characteristics suggest meanings and relationships, allowing the creation of a specific discursive specificity. It is pertinent to conjecture that by adopting aesthetic and morphological aspects similar to natural structures, bioinspired products have a great capacity to evoke memories, which in turn can facilitate the use of these products.

This article seeks to discuss the capacity that bioinspired products by formal, functional, procedural, and structural analogy have, through the adoption of aesthetic and morphological aspects, to contribute to the use of the product from the memory and pre-existing experiences. 


\section{Perceptual process: aesthetic and morphological aspects}

Anything that provokes a reaction in some sense organ is considered as a stimulus, being able to generate response by an observer through perception, considered as a process based on action, probability, and experience (Farina et al., 2011). Löbach (2001, p. 171) explains that "perception is a process by which an aesthetic appearance is transformed into meaning", in which the aesthetic aspects present in the object become responsible for generating in individuals' stimuli that will culminate in the judgment about the visual phenomena. This is exposed by Nasar (2000) when addressing the evaluative responses of the surroundings. For the author, the stimuli of the environment shape our feelings, thoughts and behavior based on the following process (See Figure 2):

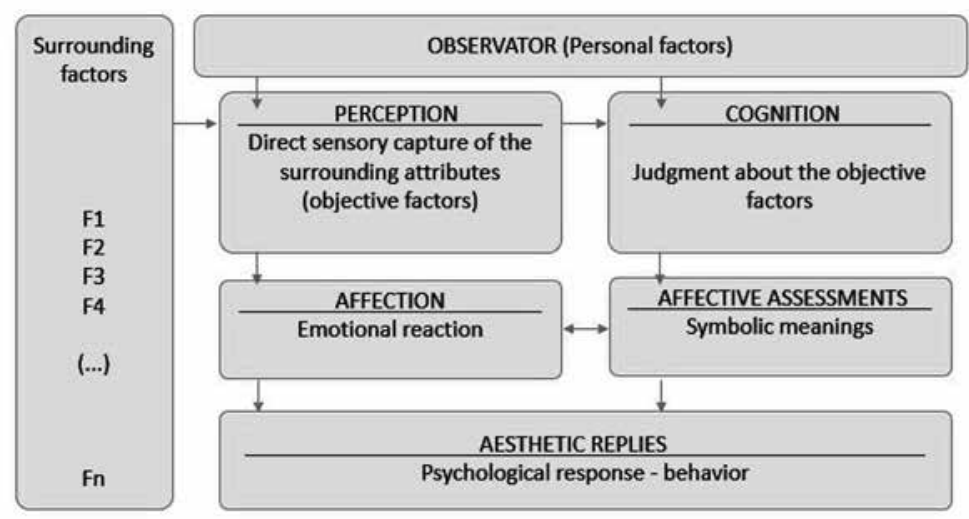

Figure 2. Evaluative responses from the surroundings

According to the author, the individual is initially exposed to the surrounding factors -shapes, colors, surfaces, among other attributes that are perceived sensorially by the observers- equipped with personal factors derived from their previous experiences and purposes. This combination, between surrounding factors and personal factors, results in aesthetic perception, which consists of direct sensory capture of the surroundings through vision (1st phase, objective), influencing the thoughts of individuals, who seek to structure, recognize, and apprehend the information (cognition - 2nd subjective phase). This allows the "objects" to be transformed into meaning, starting from the last phase, in which the perception of the characteristics of the surroundings evoke visceral feelings, which combined with the thoughts (emotional evaluations), produce reflective thoughts (cognitive evaluations), which can affect human behavior (Nasar, 2000). 
It is a subjective process, influenced by the current image of perception, the memory of each person, previous experiences, concepts of value and socio-cultural norms. For Cardoso (2013), every time an individual looks at an object it associates it with a series of values and judgments linked to individual and collective history, which makes the material artifacts have their own language, which can be translated into registration through semantic approaches, based on visual and morphological characteristics. A quality is attributed to the object, which basically does not derive from it, but from the repertoire and cultural assumptions, which contribute to the realization of a new behavior. For the author, forms are expressive of a process of signification, which consists of the exchange between what is embedded in their materiality and what can be understood/perceived by them through experiences. Therefore, any object is mediated by symbolic systems.

The meaning resides, therefore, in the users' perception, the community being determinant for what the object means, from experience, which is one of the most determinant factors of meaning. Thus, it is possible to make strategic use of memory, as way of creating correspondence between visual design, memory, and identity. The existing repertoire can be used to introduce noise and create dissonance, as well as to reinforce apparent meanings (Cardoso, 2013).

The analogy, a recurring concept in the field of biomimetics, demonstrates this capacity, from the transfer of aspects present in nature to industrial products. This demonstrates the ability to evoke memories in individuals capable of contributing to positive associations, through recognition, as well as collaborating with use, through memory and experience.

\section{Biomimicry and Biophilia}

There are many nomenclatures that relate nature to the project areas, Biomimetics, Bionics, Biodesign, among others. Fernandes (2012) comments that both terminologies were derived from the word Biotécnica that appeared as a reference in the book dated 1877 by Reverend John George Wood, "Nature's teaching's: Human Invention Articipated by Nature", and later in 1920, in Raul's book Francé, "Die Planze als Erfinder" (Plants as Inventors). Later on the word suffered a derivation, the term "Bionics" (Bionics) appearing which is related to the word "Bio" (life) and "onics" of "tecnologics" (technology). According to Arruda (1993), this term was officially introduced in 1960 at a Symposium in the USA, promoted by the air forces, where it was used by the engineer and Major Jack. E. Stelle who defined it as: "Science of systems whose functioning is based on natural systems, or which have analogies with them".

Broeck (1989) explains about a new term, Biodesign, which for this author is Bionics applied to industrial design, being more coherent with the project activity.

Later, the most recognized term today, Biomimicry, is more comprehensive, as it involves multidisciplinary and focuses on the replication of the optimal solutions observed in living organisms that survived the evolution process, and which, therefore, are the best adapted and efficient. The objective is to identify in these organisms and in their systems, what characteristics and functions have made them better adapted and to transpose such 
solutions to artificial systems, since these beings live and survive in the same environment as humans. As Benyus (1997) emphasizes:

Our beams and struts can be found on the leaves of the waterlily and on the bamboo stems; our heating and air conditioning systems are surpassed by the stable $30^{\circ}$ centigrade of the termite mound; our most sophisticated radar is deaf compared to the bat's frequency capture system. And our "smart materials" do not reach the feet of the dolphin's skin or the butterfly's proboscis. Even the wheel, which we consider to be the creation of man, was found in the tiny rotor that drives the scourge of the oldest bacterium in the world.

In this way, Benyus (1997) defines Biomimetics as a science that studies the models of nature and then imitates them, is inspired by them or their processes to solve human problems, however the solutions must be based on the triad: nature as a model, measure, and mentor. Nature as a model means inspiration and mimesis in nature's solutions for practical applications; Nature as a measure, uses the ecological standard as a parameter for innovations, since after 3.8 billion years of evolution, it has learned what works, is more appropriate, economical and durable; And, finally, nature as a mentor represents a new way of seeing and valuing it, inaugurating an era whose bases are based not on what can be extracted from it, but on what can be learned from it. These latest approaches to nature as a measure and mentor present new values, which include aspects of sustainability and respect for nature, the real revolution in this field.

Although derived from the Greek word "Biomimesis", where "bios" means life and "mimesis", imitation, it is not restricted to just an imitation of the biological form, but also considers the concept of replicating the behavior of biological organisms. According to Santos (2010), Biomimética collaborates with the philosophy of environmental design, which also has a multidisciplinary vision where many industrial sectors can replace the traditional method of design and production of consumer goods with the "method" of nature that is well more balanced and less costly for the environment.

Another more recent term that collaborates with this vision of using nature in projects is Biofilia, meaning the inherent human inclination to affiliate with nature, fundamental to people's physical and mental health and well-being (Wilson, 1986; Kellert and Wilson, 1993; Kellert, 1997, 2012). In a literal translation it means "love of living things" in ancient Greek (philia=love a/inclination to e bio=life). In general, Biophilia connects humans with nature in order to improve their well-being through an innate emotional connection. In other words, people feel a basic need to have contact with nature (Wilson, 1993; Heerwagen, 2009).

This connection is associated with an understanding of human evolution, in which more than $99 \%$ of its history has developed biologically in an adaptive response to natural forces, that is, it means that man has lived much longer in his history directly relating to nature, since cities, technological developments and other artificial inventions are considered recent in the history of evolution, and this justifies their biological tendency to feel more familiar with nature, a characteristic acquired by their evolutionary process. 
It was first cited by psychologist Erich Fromm in 1964, but it did not become popular until 1980 when biologist Edward O. Wilson pointed out how urbanization promoted a strong disconnect from nature. Stouhi (2020) adds that since the first civilizations, nature has served humanity as a natural habitat, providing shelter, food and medicine, but with modernity, industrial and technological revolutions have taken over the landscape, and most buildings were designed to affirm human domination over nature, promoting a distance between one and the other.

However, it is possible to recognize that recently there is a strong trend in the opposite direction, with a growing interest in the adhesion of biophilia in architectural and design projects. Therefore, the main strategy is to incorporate the characteristics of the natural world into the built spaces, such as water, vegetation, natural light and elements such as wood and stone, mainly exposed. The use of botanical shapes and silhouettes instead of straight lines is a fundamental feature in biophilic projects, in addition to establishing visual relationships, for example, between light and shadow (Stouhi, 2020).

Below, Figure 3 presents a schematic picture of Stephen Kellert, one of the precursors of biophilic design, which defined six elements and more than seventy attributes in order to implement biophilic experiments. Figure 4 shows the scheme of the 3 pillars of biophilic design proposed by Kellert and the architect Elizabeth F. Calabrese.

Regarding the benefits of incorporating biophilia, it is worth noting that the report " $\mathrm{Hu}$ man Spaces on the Global Impact of Biophilic Design in the Workplace" showed that environments with natural elements generate up to $15 \%$ higher levels of well-being and creativity, as well as $6 \%$ more productivity than non-biophilic environments. This perspective allows to create offices that encourage creativity, hospitals with areas that relax patients, and even schools that favor learning.

It is observed that in the Pillar of indirect experience with nature (See Figure 4), biophilia also considers using the forms and geometries of nature and biomimetics, since, among other aspects, according to Keller \& Calabrese (2015), to capture these characteristics of non-human nature technologically it can result in direct utilitarian benefits, as well as provoke admiration for the ingenuity of other lives and for the creativity of the natural world. In addition, it can also be considered that using such forms contributes to well-being by directly associating these visual characteristics, familiar to the memory repertoire of users of spaces and products. 


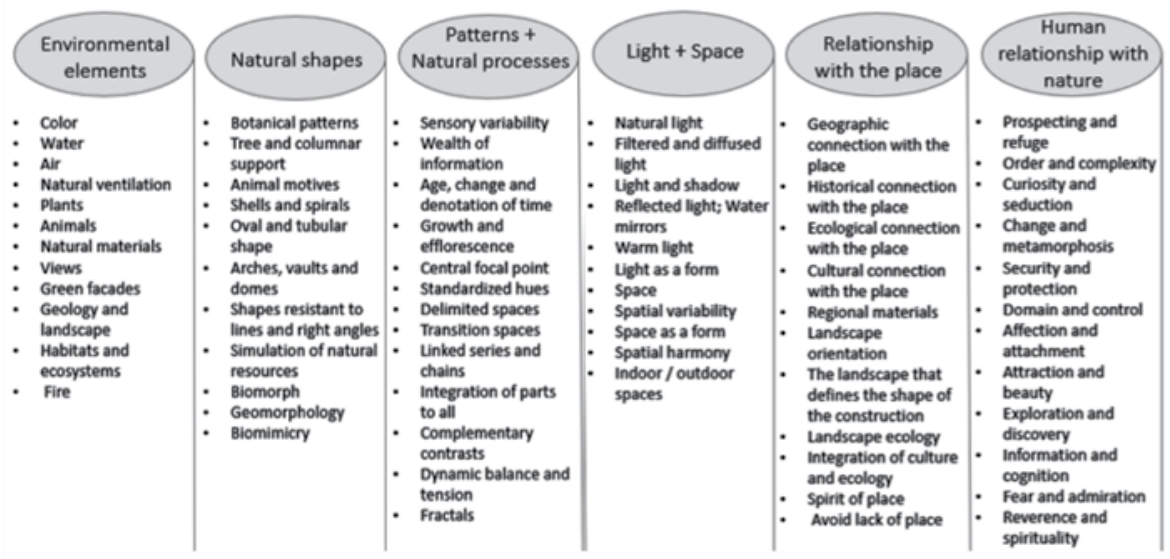

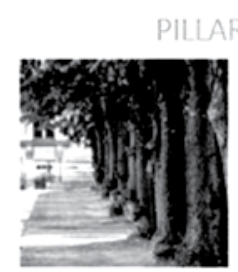

Direct

experience

with nature

- Light

- Air

- Water

- Plants

- Animals

- Sustainable materials

- Climate

- Natural landscapes and ecosystems

- Fire

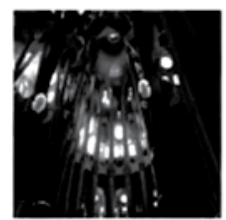

\section{Indirect}

experience with nature

- Nature images

- Natural materials

- Natural colors

- Natural light and air simulation

- Natural forms

- Evoking nature

- Wealth and information

- Age, Change and denotation of time

- Natural geometries

- Biomimicry

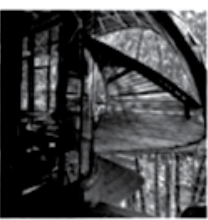

\section{Experience of}

space and place

- Prospecting and refuge

- Organized complexity

- Age, change and denotation of time

- Transition spaces

- Mobility and guidance

- Cultural and educational links with the place
Figure 3. Elements of Biophilic Design. Source: (Kellert \& Calabrese, 2015)

Figure 4. Pillars of Biophilic Design. Source: (Kellert \& Calabrese, 2015).

4 


\section{Bioinspired Artifacts}

Coelho (2008) points out that the word "artefact" refers to objects produced by human work and is therefore opposed to natural or accidental objects. It is an overly broad category, covering without distinction, technological, artistic, industrial, handcrafted objects, etc. For the author, it is useful to think of design as an area that generates artifacts, because the breadth of this concept helps to overcome distinctions that often make it difficult to compare objects produced in different contexts, or with the use of vastly different means and techniques. Regardless of the form, function or time of production, every human object is an artifact in the etymological sense of having been "made with art" (from Latin, arte factus). In other words, every object produced by human effort comes into existence through some process that transforms the idea into matter, for such a process, which in design corresponds to the act of designing, is a characteristic of humanity itself, because man is an animal that generates artifacts, eloquent vestiges of its action as culture and species. About Bioinspired Artifact this research considers those who have a clear reference and inspiration based on nature. Thus, one can translate Nature, alive (animal, vegetable) or non-living (mineral, phenomena), through analogies of its forms, functions, structures, principles, processes, systems, movements, characteristics, behaviors etc., and transpose to artificial system solutions. In this way, Analogies are related to the interpretation of the reference of nature, just focus on one or more of its aspects.

\section{Analogies}

According to the Oxford dictionary definition, Analogy is a cognitive process of transferring information or meaning from a particular subject to another particular subject. Comes from the Latin etymological origin analogĭa, ae $<$ gr. analogy, meaning 'proportion, correspondence', that is, it is a relation of similarity between different things or facts.

In classical antiquity, it was approached by the philosophers Aristotle and Plato as a shared abstraction, in which analogous objects share something in common, be it an idea, a pattern, a regularity, an attribute or a function. As a method, the analogy gains a character capable of overcoming problems through logical reasoning, as well as helping in decision making, in the different fields of creation, perception and creativity. Its application results in a wide range of solutions for different areas in accordance with the interest and content of each science. In relation to biomimetics, it is a cognitive process of interpreting Nature's references, transferring information from these to artificial systems (See Figure 5).

Soares (2016) confirms that it is quite common to use Analogy to find design solutions with reference in the natural world, as supported by this concept, it seeks to translate natural systems and contribute to the decoding of geometries, functions, and the search, among other aspects, for a better use of energy and material, thus preserving the principles of Biomimetics.

Next, the six types of Analogies that best relate to Biomimetics will be detailed, they are: Morphological, Structural, Functional, Movement, Behavioral and Symbolic Morphological. 


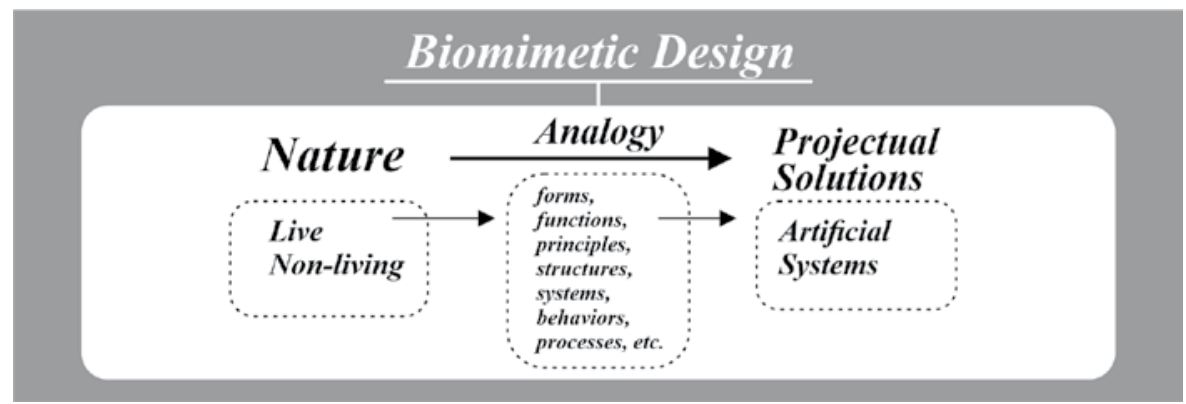

5
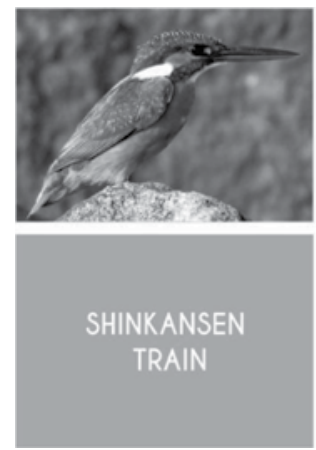

6
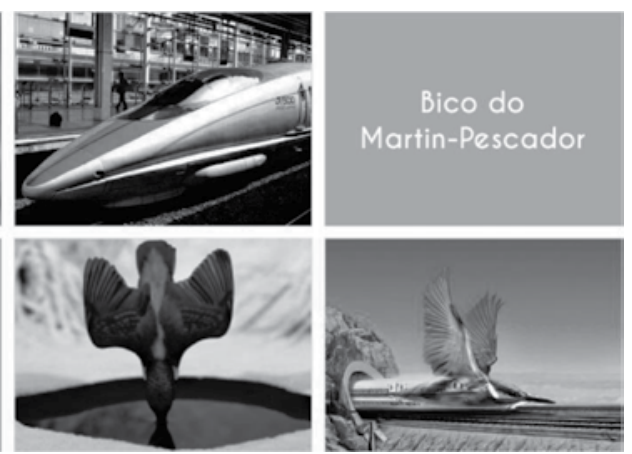

Figure 5. Scheme of the Analogy for Biomimetic Design. Source: prepared by the authors.

Figure 6. Shinkansen (Japan), the world's fastest highspeed bullet train, redesigned based on the beak of a Fisherman. Source: Versos, 2010.

\section{Morphological Analogy}

The Morphological Analogy is defined by Bonsiepe (1992) as the experimental search for models of translation of the characteristics a shape possesses with objective to transpose in projects. Thus, this type of analogy seeks to analyzes why the natural shape, the interrelationships of its geometry. According to Wilson et al. (2010), an analysis of morphological phenomena of nature facilitates and stimulates the ability to perceive details and principles present in its structure. Often, such shapes are favorable not only for aesthetics, but for efficiency gains. In summary, it can be translated as a process of interpreting the macro or microscopic forms of a natural reference, considering an external form or its parts, components, elements, or systems.

Versos (2010) brings a good example of a morphological analogy through the Shinkansen Bullet Train developed by engineer Eiji Nakatsu (See Figure 6). The project has as reference the shape of the elongated beak of the Kingfisher bird, which facilitates diving without splashing water in search of its food. In order to solve one of the big problems of the bullet 
train, which is vibration and noise, the engineer sought inspiration in the shape of this bird's beak, which resulted in an improvement with a bullet train $10 \%$ faster, consuming $15 \%$ less energy, and still, the air pressure in $30 \%$ in relation to the previous model.

\section{Structural Morphological Analogy}

It acts in the process of interpreting the forms/elements related to the support/structuring of the analyzed natural system or its parts, components, or systems. A classic example is mentioned by Thompson (1961), the most famous Tower in Europe, the Gustave Eiffel tower, a universal symbol of Paris, built in honor of the 100 years of the French Revolution, whose structural elements were based on the studies of anatomist Hermann von Meyer on the head of the human femur, (See Figure 7) which provides a wide range of movements and which is composed of a tiny set of bones called trabecular bones. Later, Meyer demonstrated this work to engineer Karl Cullmam who worked designing large cranes, and he saw that the trabeculae were more concentrated in the areas of greater stress, concluding that the femur was perfectly shaped to support large loads. Maurice Koechlin, Eiffel's assistant architect, 20 years later while designing the famous tower, would have translated his impression of that study by Cullman into his impression.

Another example is the Crystal Palace (London/England, 1951) built by Joseph Paxton for Universal Exhibition, taking its inspiration from the structure of the Amazonian Victoria-regia plant (See Figure 8). He used an illustration of one of the leaves during a lecture at the Royal Society of Arts in London, showing how to support a curved roof structure using it as a reference for the project (Pereira, 2013).

\section{Functional Analogy}

This type of analogy seeks to study the functioning of the natural physical and mechanical system; tries to understand what functions they play in the reference itself, as well as in its parts and components. In other words, the functional attributes are highlighted, specific qualities (not morphological) that can mimic the analyzed natural system, once the natural organisms have developed complex and highly adaptable skills, one can mimic these functional aptitudes and apply them to artificial artifacts. While morphologically the analogies are limited, functionally they can be multiple.

Many researchers have sought partnerships with departments of biology to obtain specific information on these functions found in some living organisms that can guide the generation of ideas for solving design problems by analogy in design. In this way, this analogy acts directly in the process of interpreting the functions observed in the natural system (reference itself, of parts, at the macro or microscopic level). Function Examples: Cleaning, adherence, protection, etc. 

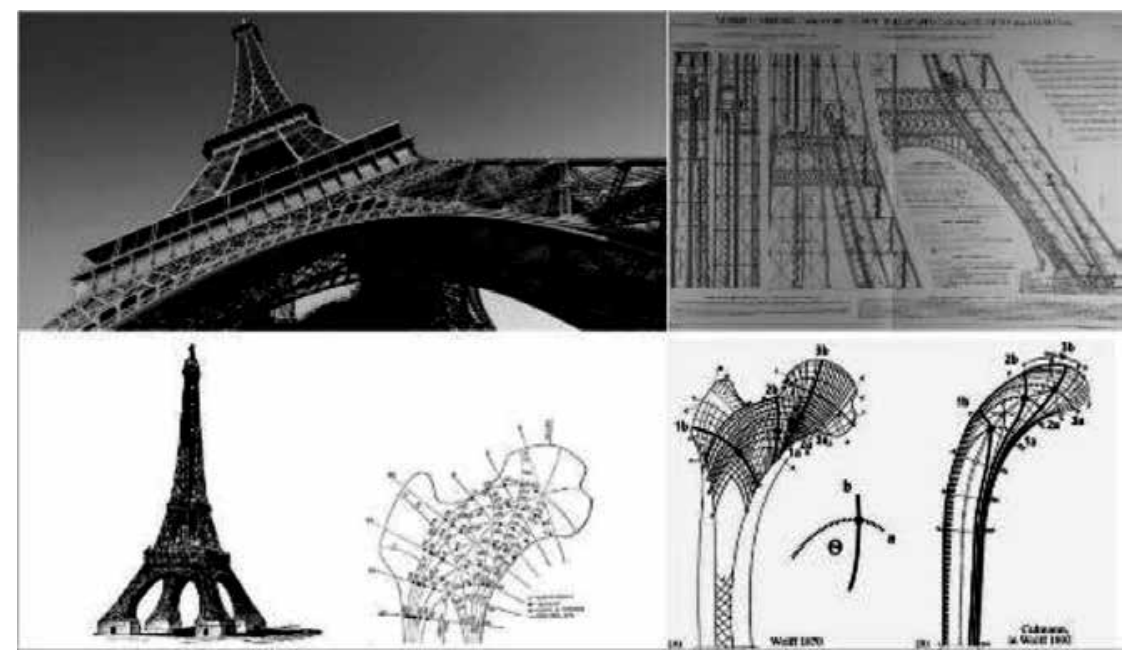

7
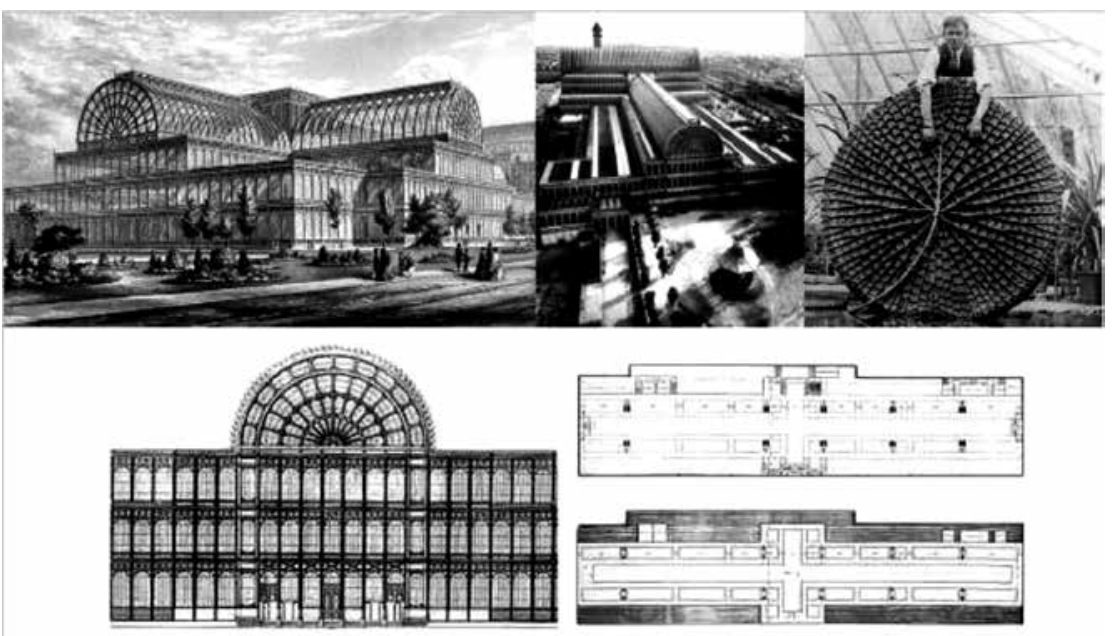

8

Figure 7. Example of structural morphological analogy of the Eiffel Tower inspired by the femur. Source: (Soares, 2016 Apud Pereira, 2013). Figure 8. Example of structural morphological analogy of the Crystal Tower inspired by Victoria Regia. Source: (Soares, 2016 Apud Pereira, 2013). 
The advantage of this analogy is that by identifying these strategies and functions, they can be applied to more than one type of artifact, serving for one or more solutions such as the case of the study of lotus leaves, in which the researcher Barthlott, identified the functions of repel water and self-cleaning their surfaces. This happens due to the angle formed by its waxy micro and nanostructures, which prevent contact with water, causing it to roll and form drops that collect dirt along the way. With this, it was identified that nanoscale rough surfaces are more hydrophobic than smoother surfaces. On the lotus leaf, the actual contact area is only $2-3 \%$ of the surface of the droplets.

This functional analogy was applied commercially to products such as Lotusan paint (See Figure 9) and, in other materials and products, such as textiles, wood or glass, through sprays (BASF Lotus Spray) that simulate the same effect of the plant. In ink, when creating micro protrusions, it repels water, cleaning itself and resisting stains for decades. Despite replicating these microstructures, the artifacts generated do not refer to the shape of the leaves themselves, but to the identified function of hydrophobia and self-cleaning (Versos, 2010).

\section{Movement Analogy}

It occurs as a process of interpretation of the elements that give movement, considering the movement of the natural reference itself (for example, the crawling movement in zigzag of the snake) or considering the movement of its parts, components, elements, or systems (for example, the movement of the snake's tongue, or the rattle of its tail, etc.) (See Figure 10).

\section{Behavioral Analogy}

It is a very peculiar analogy regarding the more specific characteristics of the reference analyzed, with a special focus on the evolutionary characteristics that made them better adapted to the environment and that guarantee their survival, or even those that differ and characterize their species from the others, that is, it acts in the process of interpreting behaviors characteristic of the analyzed natural system. (Examples: climbing on Gecko walls; rolling the embuá, changing the color of the chameleon, squid giving off paint when threatened, etc. (See Figure 11).

\section{Symbolic Analogy}

It acts in the process of personal, artistic, decorative interpretation of the natural reference, its parts, components, or systems. A representative example of this analogy is the eccentric and organic constructions of the Spanish Antoni Gaudí, with a predominance of biomorphic architecture, full of curves and counter-curves, whose elements of nature are drawn in various details. Experimenting with new forms and materials, the architect 

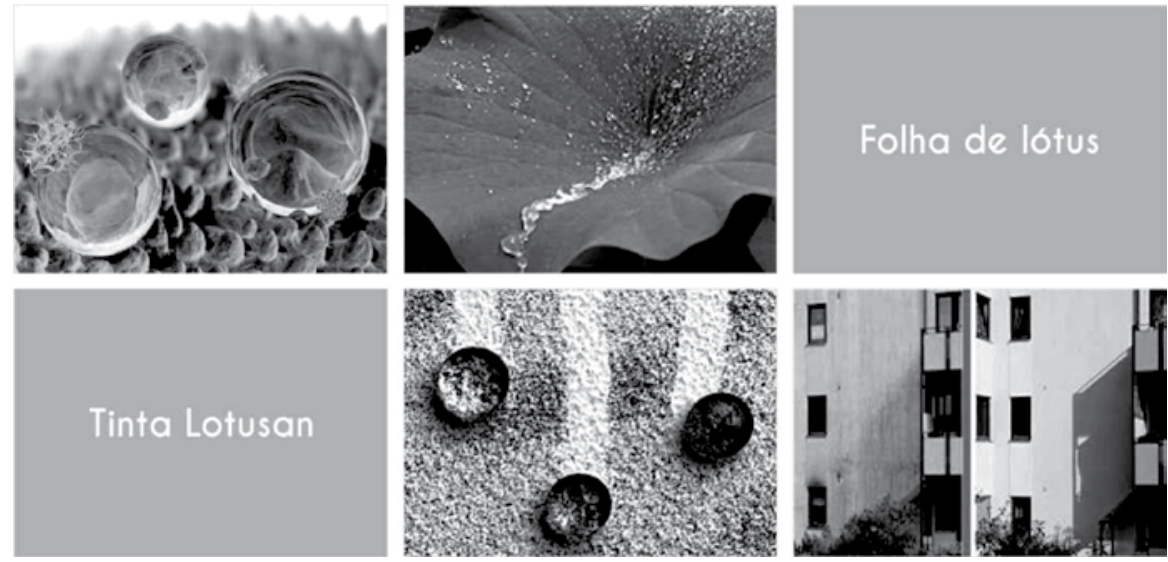

9
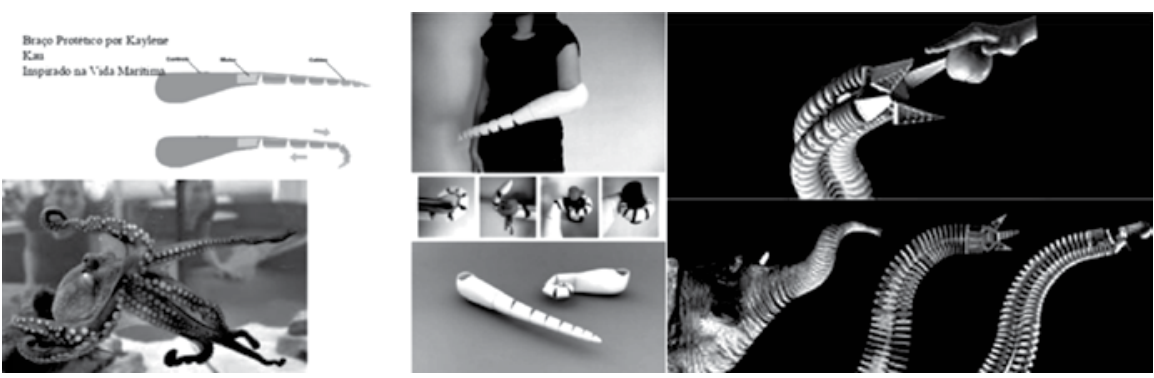

10
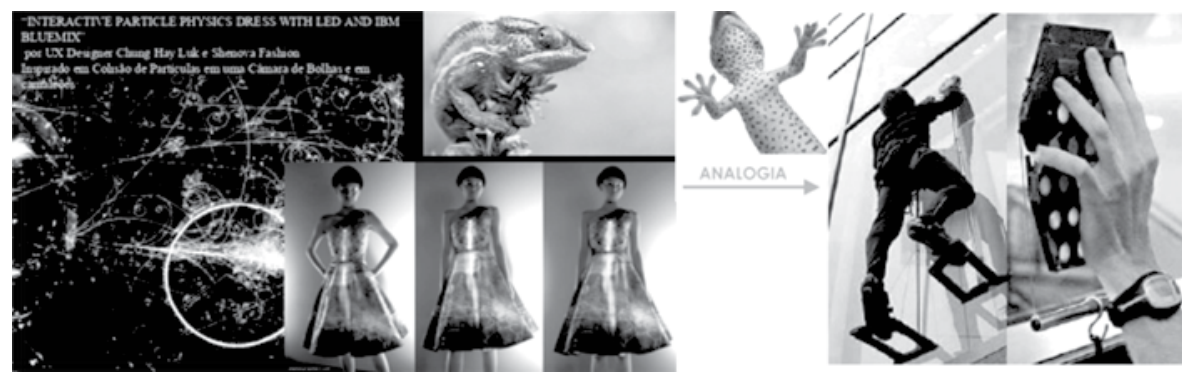

11

Figure 9. Lotusan (Germany), paint that repels water and resists stains for decades, inspired by the microstructures of lotus leaves. Source: (Soares, 2016 Apud Versos, 2010). Figure 10. Example of the prosthesis inspired by the spiral movement of the octopus's arm and another example of robotic arm inspired by the movement of the elephant's trunk grip. Source: (Prepared by the authors). Figure 11. Example of clothing inspired by the color change of the chameleon skin and artifact of climbing walls inspired by this behavioral characteristic of the Gecko. Source: (Prepared by the authors). 

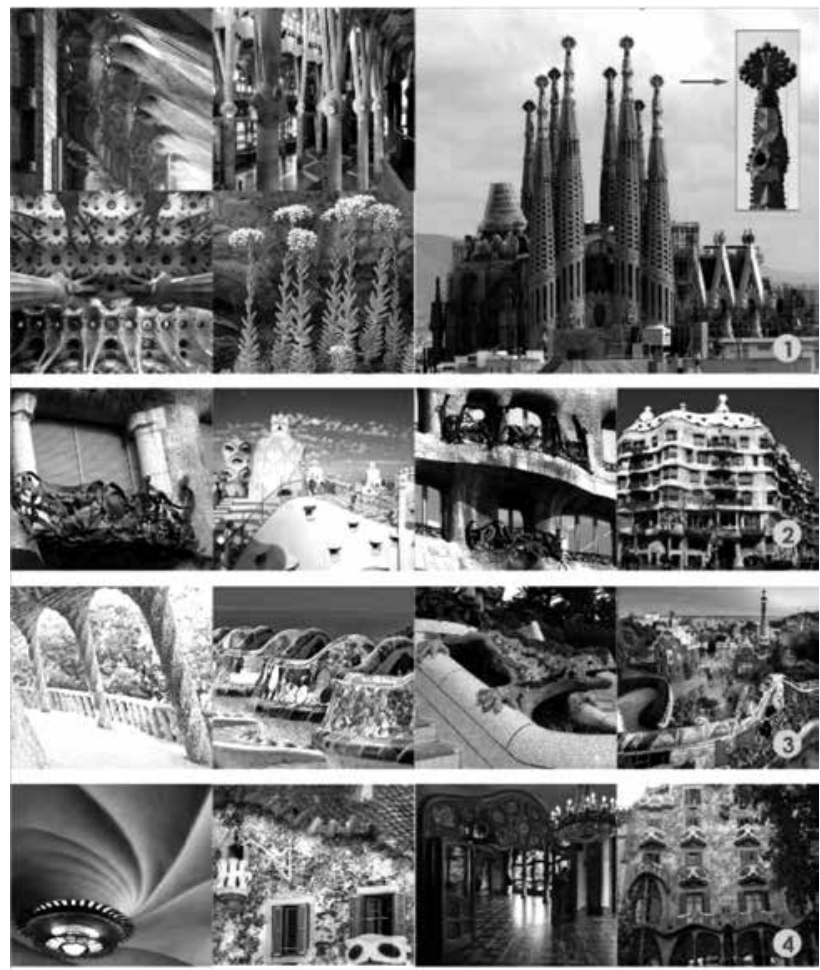

Figure 12. An

example of a symbolic analogy in the works of Antoni Gaudì. Source: Soares, 2016 Apud Pereira, 2013 and Cruz, 2013.

dedicated himself to every corner and every detail in an organic way that ended up characterizing him (See Figure 12).

His naturalistic attitude was previously approached by Thompson (1961) recalling the emblematic work of the Sagrada Familia church in Barcelona. According to Pereira (2013), Gaudí gives parabolic torsions to the facade, making use of hyperboles and spirals in various parts of the construction, filling in the work of plant motifs highlighting his naturalistic and organic attitude, in a contradiction of the Gothic architecture of the time, in which for he, the straight lines did not reflect the laws of nature with their curved shapes. Cruz (2012) also reinforces Gaudí's "natural spirit" translated into a romantic and organic air through the arrangement of leaves, stems, roots of plants, and also in the petals of flowers in this work, where the particulars refer to a forest or underwater world, presenting inside, a panoramic aspect of enchanted forest, where the play of lights and the narrow pillars densify this atmosphere. The main towers visible on the facade are inspired by the Sedum sediforme plant, being punctuated by pinnacles or flowers.

In addition to the Sagrada Família, Cruz (2012) also cites other examples of symbolic analogy that can be identified on the verandas of La Pedrera; Casa Milá, with delicate 
ornate leaves; in Park Güell, with biomorphic elements, such as reptiles and/or dragons; at Casa Batlló, covered in "scales", etc. These artistic works with cavernous spaces, colors, textures and such a peculiar luminosity are reflections of Gaudí's symbolic gaze, setting an example of this type of analogy.

As shown above in the various examples of bioinspired artifacts, it is perceived that the transposition of the forms and characteristics of elements are perceptible through a previous contact of these natural systems, familiar to the repertoire and previous experience with these systems, in other words, such artifacts evoke the memories of its users and, therefore, make its usability more intuitive.

\section{Discussion: strategic use of memory for the perception of biomimetic artifacts}

The mimesis of the solutions found from the observation of natural living objects (animal, vegetable) or non-living (mineral, phenomena), inherent to the concept of Biomimetics, can be observed as a strategy not only practical, but also as a capable resource to trigger the memory and provide communication between the artifact and the user, since according to Cardoso (2013), it is possible to strategically use the memory of individuals in projects, and thus, generate associations that refer to previous experiences. Benyus (1997) demonstrates this possibility by showing the concept of Biomimetics linked to the relationship established between natural models and human problems, with experience with the first being essential for the resolution of the second.

Memory is capable of reminding the individual of what he lived/learned from observing the natural environment, being able to generate associations through the formal-aesthetic function of bioinspired artifacts, which can be perceived as supports for the memory to from your configuration. This affects the capacity of influence that the experience with the natural environment has on the perception and communication of new artifacts, as well as on their use.

This concept corroborates with the concept of Biophilia, which exposes the human inclination to approach nature due to the evolutionary process, which provided a lasting and close coexistence between human beings and nature, developing a repertoire that can be considered and explored for project development and for communication between industrial artifacts and their users, by analogy, a strategy adopted in bioinspired artifacts. Even though flight to large urban centers has become a recurrent feature of history, biophilia shows that this has not prevented individuals from seeking contact with the natural environment. For this, we resort to means that favor coexistence, whether through direct experiences with nature, indirect experiences with nature, or experiences of space and place (Kellert \& Amp; Calabrese, 2015). The fact is that the repertoire about the natural environment is always under construction, and it can be taken to artifacts projects that aim to solve problems and communicate these solutions more assertively to users, enabling the process of using these new artifacts. 


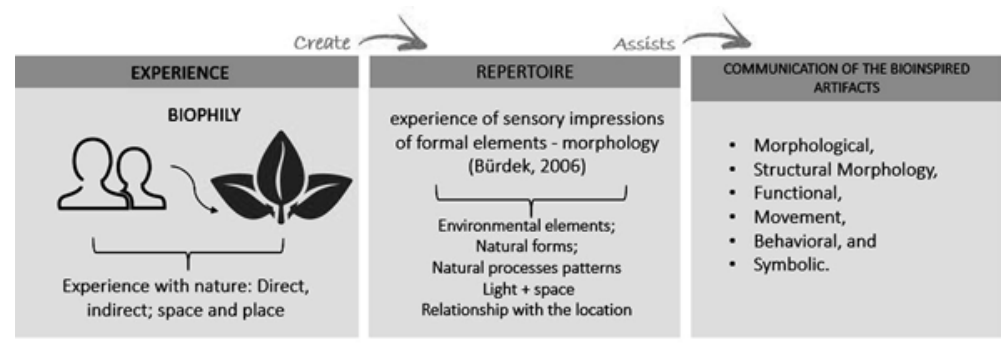

Figure 13. Analytical scheme on communication of bio-inspired artifacts. Source: (Prepared by the authors).

Regarding the use of bioinspired artifacts, it is possible to state that the aforementioned experiences with nature are capable of stimulating the human senses, provoking responses in the observer that can be used later as a parameter for the evaluation of Bioinspired artifacts and for their communication and use. This is based on what the author Nasar (2000) approaches, explaining that the stimuli of the environment, in this case, the experiences with the natural environment, would be stimuli capable of shaping the feelings, thoughts and behavior of individuals. It is conjectured that the perception built with nature (Biophilia), generates a repertoire capable of conditioning users' responses, which in turn will affect the judgment about bioinspired artifacts, positively affecting the understanding and use of this object through association (See Figure 13).

It becomes reasonable to think that experiences with the natural environment have the potential to create a repertoire capable of facilitating e experiences with new bioinspired artifacts, which adopt analogies as a design approach. It is possible to seek specific experiences, lived in the environment, and transpose them to artifacts, with the objective of generating evaluative responses consistent with the users' perception, and thus facilitate communication about the use of the artifacts.

The analogies presented previously in this work exemplify this situation, demonstrating as a projectual possibility the association of ideas through the aesthetic-formal configuration of artifacts, capable of giving memory a visual support that favors the perception of the characteristics experienced in the natural environment, and thus greater familiarization between the solutions developed (bioinspired products) and users.

In this perspective, the evaluation scheme proposed by Nasar (2000) should be considered, based on the contact between human beings and natural factors, such as those expressed by Kellert \& Amp; Calabrese (2015), being environmental elements; natural forms; natural patterns and processes; light and spaces; relationship with the place; and human relationship with nature. The contact with these factors allows the development of a repertoire related to the natural environment, which can favor communication and evaluations about bioinspired artifacts. 
From the understanding of the concept of biophilia, it is possible to observe evidence that bioinspired products have a great ability to communicate with users, demonstrating greater ease of exposing their functions, inclinations, and reason for being. Showing potential to generate greater acceptance by the public, equipped with a repertoire consistent with the aesthetic-formal function of these artifacts, due to the experience and memory inherent to human beings from experience, which facilitates communication and evokes recognition of products with solutions inspired by nature.

\section{Conclusion}

The contact with the natural environment (biophilia), linked to the understanding of communication of the artifacts, directs the designer to an approach focused on biomimetics. This is due to the memory being able to make the individual remember what he/ she experienced through associations that can be evoked from the perception of the characteristics of the bioinspired artifacts. These can act as a support for the memory, helping the first contact with the user. The experiences with natural structures have the potential to condition and influence communication and the use of bio-inspired artifacts, which carry with it the entire evolutionary experience between human beings and the natural environment that surrounds them. Being able to favor positive experiences with products that adopt natural analogies.

Based on what was exposed, it is possible to assume that the experience with nature can be considered in the process of perception and communication of bioinspired artifacts, whose evaluation is affected by the current image of our perception, by memory, and previous experiences. Cardoso (2013) brings this situation by exposing that every time we look at a new object, we associate our individual and collective history, due to its own language expressed by the aesthetics of the artifacts. The formal-aesthetic function of the artifacts can help the recognition and communication from the materiality and the perception that is achieved through previous experiences with the natural environment, with the analogy present in bioinspired artifacts being a pertinent path.

\section{References}

Arruda, Amilton. Verso una didattica nel campo biônico: ipotesi per lo sviluppo di una strategia progettuale. 1993. 185 p. Dissertação (mestrado) - Istituto Europeo di Disegn di Milano, Centro Ricerche in Strutture Naturalli.

Benyus, J. M. (1997). Biomimética: Inovação inspirada pela natureza. 6a ed. São Paulo: Ed. Pensamento-Cultrix.

Bonsiepe, Gui. (1992). Teoria e prática do design industrial: elementos para um manual crítico. Lisbon: Centro Portugüês de Design. 362 p. 
Bomfim, Gustavo Amarante. (2001) Notas de Aula sobre Design e Estética. Rio de Janeiro: PUC-RIO, Departamento de Artes \& Design-Laboratório da Representação Sensível.

Broeck, F. V. (1989). O uso de analogias biológicas. Revista Design e Interiores. São Paulo: n.15, p.97-100.

Bürdek, B. E. (2006). História, Teoria e Prática do Design Industrial. Barcelona: Ed. Gustavo Gili.

Cardoso, Rafael. (2016). Design para um mundo complexo. São Paulo: COSAC NAIFY, 2013. 264 p. ISBN 978-85-405-0098-3.

Coelho, Luiz Antonio Luzio (Org.). (2008). Conceitos-chave em Design. Rio de Janeiro: Editora PUC-Rio e Teresópolis: Editora Novas Idéias. 280p.

Cruz, André J. A. B. Arquitectura [bio]lógica,uma análise da obra de Frei Otto. 2012. 229p. Dissertação de Mestrado Integrado em Arquitectura Faculdade de Ciências e Tecnologia da Universidade de Coimbra, Coimbra, Departamento de Arquitectura.

Farina, Modesto. (2011). Psicodinâmica das cores em comunicação. São Paulo: Edgard Blücher.

Fernandes, Mara. (2012). Biomimética como conceito para uma embarcação na Ria de Aveiro. Dissertação (Mestrado) - Universidade de Aveiro, Aveiro/Portugal, Departamento de Design.

Heerwagen, J. (2009). Biophilia, health and well-being. In: CAMPBELL, L., WIESEN, A. (eds.) Restorative commons: creating health and well-being through urban landscapes.

Kellert, S.R. (1997). Kinship to mastery: biophilia in human evolution and development. United States of America: Island Press.

Löbach, B. (2001). Design industrial. São Paulo: Edgard Blücher.

Nasar, Jack L. (2000). The evaluative image of places. In W. Bruce Walsh; Kenneth H Craik; Richard H. Price. 2000. 2 ed. Person-environment psychology: new directions and perspectives, pp 117-168. New Jersey: Lawrence Erlbaum Associates.

Pereira, Inês, V.M. Arquitectura Biônica, narrativas de analogias biológicas na Arquitectura. 2013. 171p. Dissertação (Mestrado) - Departamento de Arquitectura, Porto, Faculdade de Arquitectura da Universidade do Porto.

Santos, C. (2010). O desenho como processo de aplicação da biomimética na arquitetura e no design. Revista TÓPOS. V. 4, Nº 2, p. 144 - 192. Universidade Estadual Paulista, Presidente Prudente.

Silveira, Nathalie Barros da Mota. (2018). Morfologia do objeto: uma abordagem da gramática visual/formal aplicada ao design de artefatos materiais tridimensionais. Tese (Doutorado em Design) - Universidade Federal de Pernambuco, Recife. $181 \mathrm{f}$.

Soares, T. A Biomimética e a Geodésica de Buckminster Fuller: Uma Estratégia de Biodesign. 2016. 286f. Dissertação (Mestrado em Design) - Universidade Federal de Pernambuco, Recife, Departamento de Design do Centro de Artes de Comunicação.

Stouhi, Dima. "Os benefícios da biofilia para a arquitetura e os espaços interiores" [Bringing the Outdoors Inside: The Benefits of Biophilia in Architecture and Interior Spaces] 10 Nov 2020. ArchDaily Brasil. (Trad. Sbeghen Ghisleni, Camila) Acessado 10 Abr 2021. $<$ https://www.archdaily.com.br/br/927908/os-beneficios-da-biofilia-para-a-arquitetura -e-os-espacos-interiores> ISSN 0719-8906. 
Thompson, D'Arcy Wentworth. (1961). On growth and form. 1 aed., Cambridge, Cambridge University Press.

Versos, Carlos. A.M. Design biônico: A natureza como inspiração criativa. Dissertação (Mestrado). 2010. 186p - Universidade da Beira Interior, Covilhã, Departamento de engenharia Eletromecânica.

Wilson, E. O. (1986). Biophilia: the Human Bond with Other Species. Cambridge: Harvard University Press.

Wilson, E. O. (1993). Biophilia and the conservation ethic. In KELLERT, S.R., WILSON, O.E. (Ed.). The biophilia hypothesis. United States of America: Island Press.

Wilson, Jamal O. \& Rosen, David. (2010).The effects of biological examples in idea generation. Design Studies. n. 31 p. 169-186, Elsevier.

Kellert, S.; Calabrese, E. (2015).The Practice of Biophilic Design. Disponível em: http:// www.biophilic-design.com, acesso em: 10 abr 2021.

Resumen: La función formal-estética está relacionada con la experiencia de impresiones sensoriales de elementos formales-morfología, en la que la relación entre el objeto y el usuario se da a nivel de procesos sensoriales. Esto es posible porque las cosas materiales hablan de sí mismas en términos de su configuración, lo que permite diseñar objetos que evocan recuerdos. Este artículo tiene como objetivo mostrar la Analogía como un camino para el desarrollo comunicacional de los artefactos industriales, que pueden enfatizar sus usos a través de memorias y anticipos de experiencias con estructuras naturales. Para ello, presenta una revisión de la literatura que enfatiza el carácter comunicativo de los artefactos biomiméticos y su capacidad para evocar la memoria como estrategia de proyecto.

Palabras clave: Comunicación - Estética - Memoria - Experiencia - Diseño de producto Biomimetismo - Analogía - Biofilia

Resumo: A função estética-formal está relacionada à experiência de impressões sensoriais de elementos-morfologia formal, em que a relação entre o objeto e o usuário ocorre ao nível dos processos sensoriais. Isso é possível porque as coisas materiais falam de si mesmas em termos de sua configuração, tornando possível projetar objetos que evocam memórias. Este artigo tem como objetivo mostrar a Analogia como um caminho para o desenvolvimento comunicacional de artefatos industriais, podendo enfatizar seus usos por meio de memórias e experiências prévias com estruturas naturais. Para isso, apresenta uma revisão da literatura enfatizando o caráter comunicacional dos artefatos biomiméticos e sua capacidade de evocar a memória como estratégia de projeto.

Palavras chave: Comunicação - Estética - Memória - Experiência - Desenho de produto Biomimética - Analogia - Biofilia 